\title{
Financial Derivatives in Corporate Tax Aggressiveness
}

\author{
BENDI DEVI* \\ Politeknik Keuangan Negara STAN \\ SUBAGIO EFENDI \\ University of Technology Sydney, Business School, Ultimo NSW 2007, \\ Australia
}

\begin{abstract}
The purpose of this study is to investigate the utilization of derivative financial instruments in tax aggressiveness activities. The study is conducted by analyzing the fair value of derivative financial assets and liabilities in total and categorized it into hedging and speculative (non-hedging) designations to identify which type of derivatives are used for tax avoidance. The results of the analysis reveal that cash effective tax rate (Cash ETR) is negatively associated with the fair value of hedging derivative assets. This indicates that firms are reducing tax payment by delaying the realization of derivative gains designated for hedging. Furthermore, Cash ETR is found to be negatively (positively) associated with the fair value of non-hedging derivative assets (liabilities). This indicates that firms are delaying the realization of gains while accelerating the realization of losses on non-hedging derivatives to reduce tax payment. Moreover, GAAP ETR is positively associated with the fair value of the non-hedging derivative liabilities, indicating that there is a reduction of income tax expense through accelerating the realization of non-hedging derivative losses thus it can be implied that firms are utilizing derivative financial instruments in earning management activity to minimize their tax burden. This study contributes to the existing literature and public policy by providing evidence on the use of financial derivatives in tax aggressiveness along with policy recommendations related to tax implications of financial derivative transactions since, up to the time of this publication, Indonesia has not had specific tax provision which regulate taxation on financial derivative transactions.
\end{abstract}

Keywords: Tax Aggressiveness, Derivative Financial Instruments, GAAP ETR, Accounting Treatment

Intisari: Tujuan penelitian ini adalah untuk menginvestigasi pemanfaatan instrumen keuangan derivatif dalam aktivitas agresivitas pajak. Penelitian dilakukan dengan menganalisis nilai wajar aset dan liabilitas derivatif keuangan secara total dan menggolongkannya berdasarkan desain lindung nilai dan spekulatif (non-lindung nilai) untuk mengidentifikasi jenis derivatif yang digunakan untuk penghindaran pajak. Hasil analisis menunjukkan cash effective tax rate (Cash ETR) berasosiasi negatif signifikan dengan nilai wajar aset derivatif lindung nilai. Hal ini menunjukkan bahwa perusahaan mengurangi pembayaran pajak dengan menunda realisasi laba derivatif yang didesain lindung nilai. Selanjutnya, Cash ETR ditemukan berkorelasi negatif (positif) signifikan dengan nilai wajar aset (liabilitas) derivatif non-lindung nilai. Hal ini mengindikasikan

* Corresponding author: bendidevi90@gmail.com 
bahwa perusahaan menunda realisasi laba sekaligus mempercepat realisasi rugi derivatif non-lindung nilai untuk mengurangi pajak yang dibayar. Kemudian, GAAP effective tax rate (GAAP ETR) berkorelasi positif signifikan dengan nilai wajar liabilitas derivatif non-lindung nilai, mengindikasikan bahwa terjadi pengurangan beban pajak melalui percepatan realisasi rugi derivatif non-lindung nilai sehingga dapat dikatakan juga bahwa perusahaan memanfaatkan instrumen keuangan derivatif dalam aktivitas manajemen laba untuk meminimalkan beban pajak. Penelitian ini berkontribusi pada literatur yang ada dan kebijakan publik dengan memberikan bukti atas penggunaan derivatif keuangan pada agresivitas pajak bersama dengan rekomendasi kebijakan terkait implikasi pajak atas transaksi derivatif keuangan karena, sampai saat publikasi ini, Indonesia belum memiliki ketentuan pajak spesifik yang mengatur pengenaan pajak atas transaksi derivatif keuangan.

Kata Kunci:Agresivitas Pajak, Instrumen Keuangan Derivatif. GAAP ETR, Pemulihan Akuntansi

\section{Introduction}

Indonesia has witnessed a dramatic increase in financial derivative transactions over the last two decades. The transaction volume increased from Rp17.472,53 billion in 2001 to Rp60.705,55 billion in 2009 (Murwaningsari, 2011). Furthermore, following Bank of Indonesia's plan to protect systemic risk in the financial market through a derivative clearing house operation starting in 2018 (Amindoni, 2016), Wyman (2013) predicted that there would be a significant increase in derivative transactions if such clearing house exists. Thus, financial derivative transactions in Indonesia are expected to continue increasing in the future years.

Derivatives are the primary financial risk management tools (Goradia). A party uses derivatives to transfer risk to another party while at the same time receives different risk or pays a premium for transferring the risk (Victor, 2008). Moreover, derivatives can also be used by managers to manage earning (Zeng, 2014; Barton, 2011; Pincus and Rajgopal, 2002). On the other hand, firms can use derivatives to reduce earnings volatility thus reduce their tax liabilities (Schizer, 2000; Zeng, 2001; Donohoe, 2011a; Donohoe, 2011b; Donohoe, 2014; Zeng, 2014; Donohoe, 2015; Lee, 2016). Hence, the use of derivatives is also related to tax aggressiveness activities.

Tax aggressiveness can be defined as any activities conducted by taxpayers to reduce their tax liabilities. In its relation to derivatives, Lee (2016) argued that 
derivatives could minimize tax payment in several ways: (1) risk management theory suggests that firms facing convex tax functions can minimize expected tax liabilities by hedging to reduce income volatility (Smith and Stulz, 1985); (2) firms can use hedging derivatives to increase debt capacity by smoothing book earning (Graham and Smith, 2002); (3) firms can benefit from the tax regulation ambiguity to coordinate timing, character, and source of derivative's gains and losses; and (4) derivative complexities make it difficult for tax authorities to detect derivative-based tax aggressiveness.

In its relation to derivative-based tax aggressiveness, derivatives are characterized by many groups including academics, law-makers and regulators as a significant threat to global tax revenue and are classified by the Organization for Economic Cooperation and Development (OECD) as a leading source of corporate tax non-compliance (Donohoe, 2015). However, the existing studies provide sparse evidence on the association between derivatives and tax aggressiveness. Donohoe (2011a) finds that new users of derivatives experience a significant reduction in their tax payment. Furthermore, Oktavia and Martani (2013) find that the higher of the fair value of derivatives in the financial statement, the more Indonesian firms involved in tax aggressiveness activity.

This study investigates derivative-based tax aggressiveness at a more exhaustive level in revealing how derivatives are used to avoid taxes by the Indonesian firms. The study provides evidence that firms in Indonesia are:

1. In general, defer realization of gains while at the same time accelerate the realization of losses on derivatives to reduce current year tax payment and accelerate the realization of losses on derivatives to minimize income tax expense;

2. Defer realization of gains on hedging derivatives to reduce current year tax payment; and

3. Defer realization of gains on non-hedging derivatives while at the same time accelerate the realization of losses on non-hedging derivative to reduce current year tax payment and accelerate the realization of non-hedging derivative's losses to reduce tax payment. 
These findings suggest that firms involved in aggressive tax planning are benefitted from the ambiguity of tax provisions by coordinating character, source, and timing of derivative's gains and losses to avoid taxes.

\section{Theoretical Framework and Hypothesis Development}

\subsection{Accounting Treatment on Financial Derivatives}

Accounting for derivatives is regulated under Financial Accounting Standards (Pernyataan Standar Akuntansi Keuangan/PSAK) number 55 and 60 which mainly adopted International Accounting Standards (IAS) number 32 and 39 concerning Financial Instrument: Recognition and Measurement, and Financial Instruments: Disclosure, respectively. The Accounting standards require derivatives to be recorded in the balance sheet as either derivative assets or liabilities at their fair value. Derivative assets (liabilities) represent cumulative unrealized gains (losses) on derivatives regardless of their hedge designation. However, the recognition of gains and losses in the income statement varies depending on the hedge designation. Firms can use hedge accounting if the requirements under paragraph 88 of PSAK 55 are satisfied. The hedge accounting classifies hedging transactions as a fair value hedge, cash flow hedge, and hedge of a net investment in a foreign entity. Furthermore, the main benefit of applying hedge accounting is that gains (losses) on hedging instruments are recognized in the same period as losses (gains) on hedged items.

Under PSAK 55, for fair value hedge, changes in fair value of derivatives and hedged items are directly recognized in the income statement. For cash flow hedge, the effective portion of hedges are first recorded in the equity reserve or "Other Comprehensive Income" then reclassified realized gains or losses in the income statement at the same period as when forecasted cash flow affect earnings. Unrealized or realized gains on non-hedging transactions or ineffective portion of hedging transactions are immediately recorded in the income statement.

PSAK 60 requires qualitative and quantitative disclosure concerning derivative transactions. Firms are required to disclose their main objectives in using financial derivatives as well as the fair value amount of derivative assets and liabilities. Besides, 
firms are also required to reveal derivatives separately based on their hedge designation. These disclosure requirements provide data to be hand-collected for this study as data needed are the fair value of derivative assets and liabilities amounting as total value and amounting segregated into as hedging and non-hedging designations value.

\subsection{Tax Provisions on Financial Derivatives in Indonesia}

Under Article 4 Paragraph (2) of Indonesian Income Tax Law (Undang-Undang Pajak Penghasilan), derivative transactions are taxed using withholding final income tax regulated by specific Government Regulation (Peraturan Pemerintah). However, the Government Regulation does not exist until this study is published. The absence of the specific tax regulation urged some taxpayers to argue that derivative transactions are taxed based on applicable financial accounting standard as stated in the explanatory paragraph of Article 28 of General Tax Provisions Law (Undang-Undang Ketentuan Umum dan Tata Cara Perpajakan) which stipulated that if the tax law does not specifically regulate particular transactions, the transactions are recognized based on the generally accepted accounting standards in Indonesia. Hence, derivatives are taxed based on PSAK 55. However, under Article 10 of Income Tax Law, an income/outcome are taxed based on realization principle which requires capital inflow (outflow) to (from) the taxpayers. Under this provision, gains and losses on derivatives should be recognized when realized.

Under the definition of income under Article 4 Paragraph (1) of Income Tax Law, gains on derivatives are taxed regardless of the hedging designation. On the other hand, losses on derivatives which are recognized as deductible expense should be associated directly or indirectly with taxpayer's business activities (Article 6 Paragraph (1) of Income Tax Law). The deductible expenses should be in the form of necessary expenditure to earn, to collect and to preserve income. Under this provision, loss on derivatives that are held for a speculative purpose cannot be deducted from taxpayer's gross income. However, opposite to the speculative purpose, the law does not specify requirements for derivatives to be classified as a hedging instrument and also does not require taxpayers to apply hedge accounting for tax purpose. This loophole opens an 
opportunity for taxpayers to "manage" sources of derivative's losses. Furthermore, the risk of tax avoidance is intensified when the derivative transactions are done between related parties with different statutory corporate income tax rate.

To conclude, Indonesia has not owned specific tax regulation concerning financial derivative transactions until this research is published. Consequently, under the general income tax principle, gains on derivatives are taxed regardless of the sources of the gains. Conversely, losses on derivatives should be associated directly or indirectly with taxpayer's business activities to be deductible against gross income. Furthermore, there is no explicit limitation in the tax regulation regarding formal classifications of derivative transactions as hedging or non-hedging.

\subsection{Derivative-based Tax Aggressiveness}

Tax aggressiveness is defined as the taxpayer's activities to reduce their tax payment. Hanlon and Heitzman (2010) explained tax aggressiveness represent a tax planning strategies continuum where benign strategies lie at one end while the other end represents aggressive tax planning strategies (aggressiveness, evasion, non-compliance and sheltering). The degree of aggressiveness measurement is not clearly defined by law. It is tax authorities effort to determine its aggressiveness. In general, tax planning can be classified as aggressive if the applied strategies are not associated with the taxpayer's primary business activities.

Donohoe (2015) argued derivatives facilitate tax planning strategies along the entire continuum. One end represents a benign strategy as a byproduct effect of the usage of derivatives: risk management theory suggests that firms facing convex tax functions can reduce expected tax liabilities by hedging to reduce income volatility (Smith and Stulz, 1985); firms can use hedging derivative to increase debt capacity by smoothing book earning (Graham and Smith, 2002). At the other continuum, derivatives facilitate a more aggressive tax planning strategies which allow firms to coordinate source, character, and timing of gains and losses recognition. Also, Lee (2016) claimed that derivative complexity might make it difficult for the tax authority to detect an aggressive derivative-based tax planning. 


\subsection{Hypothesis development}

Firms coordinate timing recognition of gains and losses to avoid current year tax payment as there are different gains and losses recognition between accounting standard and tax regulation. Tax regulation allows firms to defer unrealized gains on derivative until its realization while accounting standard recognizes unrealized gains on derivatives as income. Realization principle of tax rule benefits firms as they do not pay taxes until derivative gains are realized (i.e. a derivative position is closed) while fair value accounting benefits firms as they achieve increased earning prior realization of derivative's unrealized gains. Thus, more substantial derivative assets may represent deferral tax strategies. On the other hand, smaller derivative liabilities may represent a greater tax aggressiveness. Firms immediately realize losses on derivatives by closing derivative position to reduce taxable income. Realizing losses on derivative removes associated derivative liabilities in a balance sheet. Thus, the study proposes the following directional hypotheses:

Hypothesis 1 (H1). The fair value of total derivative assets (liabilities) is positively (negatively) associated with tax aggressiveness.

Realization principle of tax regulation allows firms to delay recognition of gains and losses on hedging derivatives and gains and losses of hedged items until a derivative position is closed while accounting standard requires firms to recognize fair value gains and losses on derivatives and hedged items in the financial statement. Firms delay realization of gains until the underlying transaction occurs and accelerate the realization of losses to avoid taxes. Therefore:

Hypothesis 2 (H2). The fair value of hedging derivative assets (liabilities) is positively (negatively) associated with tax aggressiveness.

Indonesia's tax regulation does not require matching principle on gains and losses of derivatives and hedged item's recognition. Thus, firms will have an opportunity not to apply hedge accounting for their hedging transactions. The absence of a specific tax regulation of derivative allows firms to recognize losses on non-hedging derivative to deduct taxable income by coordinating derivative losses sources. For tax purpose, firms 
delay gains and accelerate losses realization of non-hedging derivatives to avoid taxes. Thus:

Hypothesis 3 (H3). The fair value of non-hedging derivative assets (liabilities) is positively (negatively) associated with tax aggressiveness.

\section{Research Method}

\subsection{Sample Selection}

The data required to test the proposed hypotheses were gathered from publiclylisted firm's financial statements from the year 2011 to 2015 which are available in the Indonesia Stock Exchange website (www.idx.co.id). The sample used is non-financial service firms with substantial derivative transactions and positive pretax income along 2011 to 2015. Financial service firms are excluded due to different regulation concerning derivative transactions. Firms with negative pretax income are omitted to avoid ambiguity that the low ETRs have arisen since the firms experience losses rather than the derivative usage. ETRs with a value higher (less) than $1(0)$ is treated as a missing value. Table 1 presents the sample selection procedure.

Table 1

Sample Selection

\section{Sample Selection}

Public firms listed on Indonesia Stock Exchange 521

Less: financial firms

Less: firms without derivative transactions

Less: firms with negative pretax income

Sample firms

Firm year observations $(47 \times 5)$

Less: Incomplete data

Less: Cash ETR greater (less) than $1(0)$

Less: GAAP ETR greater (less) than 1 (0) 6

\begin{tabular}{ll}
\hline Observations with dependent variable Cash ETR & 216 \\
\hline Observations with dependent variable GAAP ETR & 222 \\
\hline
\end{tabular}




\subsection{Research Design}

To test the first hypothesis (the association between derivatives and tax aggressiveness), the proposed model is as follow:

$$
\begin{aligned}
\text { ETR }_{\text {it }}= & \beta_{0}+\beta_{1} \text { FVD_A }_{\text {it }}+\beta_{2} \text { FVD_L }_{\text {it }}+\beta_{3} \text { LEV }_{\text {it }}+\beta_{4} \text { ROA }_{\text {it }}+\beta_{5} \text { SIZE }_{\text {it }}+ \\
& \beta_{6} \text { CAPINT }_{\text {it }}+\varepsilon_{\text {it }} \ldots \ldots \ldots \ldots \ldots . . .(1)
\end{aligned}
$$

The following model is used to test the second hypothesis (the association between hedging derivatives and tax aggressiveness):

$$
\begin{aligned}
& \text { ETR }_{\text {it }}=\beta_{0}+\beta_{1} \text { FVHD_A }_{\text {it }}+\beta_{2} \text { FVHD_L }_{\text {it }}+\beta_{3} \mathrm{LEV}_{\text {it }}+\beta_{4} \text { ROA }_{\text {it }}+\beta_{5} \text { SIZE }_{i t}+ \\
& \beta_{6} \mathrm{CAPINT}_{\mathrm{it}}+\varepsilon_{\mathrm{it}}
\end{aligned}
$$

To test the third hypothesis (the association of non-hedging derivatives and tax aggressiveness), the model is as follow:

$$
\begin{aligned}
& \text { ETR }_{\text {it }}=\beta_{0}+\beta_{1} \text { FVHD_A }_{\text {it }}+\beta_{2} \text { FVHD_L }_{\text {it }}+\beta_{3} \text { FVNHD_A }+\beta_{4} \text { FVNHD_L }+ \\
& \beta_{5} \mathrm{LEV}_{\text {it }}+\beta_{6} \mathrm{ROA}_{\text {it }}+\beta_{7} \mathrm{SIZE}_{\text {it }}+\beta_{8} \mathrm{CAPINT}_{\text {it }}+\varepsilon_{\mathrm{it}}
\end{aligned}
$$

Where:

ETR: annual effective tax rate for firm $\mathrm{i}$ in year $\mathrm{t}$;

FVD_A: fair value of derivative assets;

FVD_L: fair value of derivative liabilities;

FVHD_A: fair value of hedging derivative assets;

FVHD_L: fair value of hedging derivative liabilities;

FVNHD_A: fair value of non-hedging derivative assets;

FVNHD_L: fair value of non-hedging derivative liabilities;

The dependent variable of ETR is segregated into two measures, CASH_ETR and GAAP_ETR.CASH_ETR is defined as annual cash tax paid divided by pre-tax income while GAAP_ETR as tax expense divided by pre-tax income. CASH_ETR captures aggressive tax strategies that reduce tax payment whereas GAAP_ETR captures strategies that minimize tax expense which reflects earning management activity. The 
independent variables of the derivative's fair value are measured as a total, hedging for accounting purpose and non-hedging for accounting purpose fair value divided by lagged total assets.

This study also includes control variables that are known affecting the effective tax rate. The control variables are:

LEV: leverage, measured as total debt divided by total assets;

ROA: return on asset, measured as pre-tax income divided by total assets;

SIZE: firms' size, measured as the natural logarithm of total assets;

CAPINT: capital intensity, measured as total fixed asset divided by lagged total assets.

\section{Results}

Table 2 presents the descriptive statistics of the dependent, independent variables and control variables. It shows the mean, median, standard deviation, minimum and maximum value. Table 2 shows derivative users in this research have a lower effective tax rate than in the previous study by Oktavia and Martani (2013). The mean (median) of GAAP_ETR is $25.13 \%$ (25.12\%) while mean (median) reported in Oktavia and Martani (2013) is $28.7 \%$ (25.47\%). These differences show that firms in this research are more likely to involve in aggressive tax planning than firms in Oktavia and Martani (2013). Firms in this research are relatively larger than those in Oktavia and Martani (2013). This supports a theory that large firms are likely to avoid a significant increase in income due to taxation (Scott, 2009).

The mean of derivative assets (liabilities) is 0.004393 (0.003261) compared to lagged assets. These show derivative assets are somewhat larger than derivative liabilities. On the other hand, the unpresented in descriptive statistics table, comparison of the fair value of derivatives with annual pretax income results the mean of derivative assets (liabilities) fair value is $8.88 \%(1.41 \%)$ compared to pretax income. These values imply firms in the sample have higher unrealized gains than unrealized losses on 
derivative as derivative assets (liabilities) are defined as cumulative unrealized gains (losses) on derivative. These values provide preliminary support to the three hypotheses.

The mean of hedging derivative assets (liabilities) and non-hedging derivative assets (liabilities) is 0.001518 (0.000296) and 0.002850 (0.002911), respectively. These values show that derivative transactions held for accounting purpose-hedging are smaller than non-hedging derivative transactions. This relatively small value of hedging derivative transactions could happen for several reasons. First, firms do not intend to engage in hedging transactions. Second, firms intend to engage in hedging transactions but do not apply hedge accounting due to, either, firms are intentionally do not apply it or do not meet the requirements to apply the accounting treatment.

Table 2

Descriptive Statistics

\begin{tabular}{llllll}
\hline \multicolumn{1}{c}{ Variables } & \multicolumn{1}{c}{ Mean } & \multicolumn{1}{c}{ Median } & St. Deviation & Minimum & Maximum \\
\hline CASH_ETR & 0.307346 & 0.274697 & 0.163614 & 0.000516 & 0.974090 \\
GAAP_ETR & 0.251347 & 0.251281 & 0.123810 & 0.000406 & 0.796777 \\
FVD_A & 0.004393 & 0.000000 & 0.014630 & 0.000000 & 0.107177 \\
FVD_L & 0.003261 & 0.000000 & 0.012506 & 0.000000 & 0.115836 \\
FVHD_A & 0.001518 & 0.000000 & 0.007754 & 0.000000 & 0.068211 \\
FVHD_L & 0.000296 & 0.000000 & 0.001100 & 0.000000 & 0.007640 \\
FVNHD_A & 0.002850 & 0.000000 & 0.012754 & 0.000000 & 0.107177 \\
FVNHD_L & 0.002911 & 0.000000 & 0.012473 & 0.000000 & 0.115836 \\
LEV & 0.521753 & 0.506248 & 0.168921 & 0.157710 & 1.020094 \\
ROA & 0.133654 & 0.081733 & 0.134002 & 0.011834 & 0.884856 \\
SIZE & 29.554660 & 29.565740 & 1.457323 & 23.655960 & 33.134050 \\
CAPINT & 0.356649 & 0.291518 & 0.274520 & 0.000204 & 1.979008 \\
\hline
\end{tabular}

Table 3 reports the Pearson Correlation Matrix between ETRs and derivative fair values. In general, there is a significant correlation between effective tax rate and derivative measures, but the correlation coefficients are reasonably small in magnitude. Cash effective tax rate is negatively correlated with a fair value of total derivative assets and hedging derivative assets. The correlation between CASH_ETR and FVD_A (FVHD_A) is $-0.115(-0.163)$. These values are in line with hypothesis H1 and H2 regarding the higher the derivative assets, the smaller the taxes paid. GAAP effective tax rate is positively correlated with FVD_A (FVD_L) and FVNHD_A (FVNHD_L) 
with a coefficient correlation of $0.151(0.246)$ and $0.137(0.239)$, respectively. The presented values show there is the different direction of correlation between Cash ETR and derivative assets and GAAP ETR and derivative assets. This may arise due to the existence of a temporary difference between accounting standard and tax regulation. Accounting standard allows firms to recognize unrealized gain while tax regulation holds on to the realization principle. Thus, a higher value of derivative unrealized gains could lead to higher tax expense in the income statement.

Table 3

Pearson Correlation Matrix

\begin{tabular}{|c|c|c|c|c|c|c|c|c|}
\hline Variables & CASH_ETR & AAP_ETR & FVD_A & FVD_L & FVHD_A & FVHD_L & FVNHD_A & FVNHD_L \\
\hline$\overline{\mathrm{CASH} E \mathrm{ETR}}$ & 1 & & & & & & & \\
\hline GAAP_ETR & 0.57 & 1 & & & & & & \\
\hline FVD_A & -0.115 & 0.151 & 1 & & & & & \\
\hline FVD_L & 0.053 & 0.246 & 0.695 & 1 & & & & \\
\hline FVHD_A & -0.163 & 0.063 & 0.288 & -0.042 & 1 & & & \\
\hline FVHD_L & 0.080 & 0.097 & -0.039 & 0.076 & 0.043 & 1 & & \\
\hline FVNHD_A & -0.020 & 0.137 & 0.944 & 0.741 & -0.043 & -0.055 & 1 & \\
\hline FVNHD L & 0.048 & 0.239 & 0.702 & 0.996 & -0.045 & -0.011 & 0.748 & 1 \\
\hline
\end{tabular}

Bold coefficients are significant from zero at the 10 percent level.

Table 4 presents the first hypothesis testing. It shows cash ETR is negatively (positively) associated with total derivative assets (liabilities). The association coefficient between CASH_ETR and total derivative assets (liabilities) is -3.428468 (3.393829) with probability 0.0001 (0.0001) on one-tailed t-test. These associations imply that the higher (lower) derivative assets (liabilities), the smaller the cash effective tax rate. These results suggest that firms, in general, reduce current year tax payment by both delaying realizations of gains and harvesting or accelerating realization of losses on derivatives.

On the other hand, GAAP ETR is positively associated with derivative liabilities. The coefficient association is 2.066456 with probability 0.0097 on one-tailed t-test. This finding suggests that firms harvest losses on derivatives to reduce tax expense rather than delay recognition of gains. This also suggests firms manage earnings through minimizing tax expense. 
Table 5 reports the second hypothesis testing result. Cash ETR has a significant negative association with hedging derivative assets but not with liabilities. The association coefficient is -5.363221 with probability 0.00005 on one-tailed t-test. This result suggests that firms delay recognizing gains on derivatives to reduce current year tax payment rather than harvest hedging derivative's losses. The association between Cash ETR and hedging derivative liabilities might arise due to the offset of losses on derivatives with gains on hedged items as required by accounting standard thus resulting in relatively constant in taxable income amount.

GAAP ETR is not significantly associated with both hedging derivative assets and liabilities. It suggests firms do not manage earning through tax expense using hedging financial derivatives. To apply hedge accounting, firms are required not only to assess the derivative value as its hedging instrument but also the associated hedged item value. On effective hedging, there exists an offset between hedging instruments and hedged items. The tight effectiveness range required on accounting standard that is between $80 \%-125 \%$ will significantly offset gains and losses on hedging instruments and hedged items. This might cause the derivative use on hedging activities does not affect the accounting income substantially. Thus, it does not affect tax expense variation significantly.

Table 4

H1. The association between ETRs and Total Derivative Assets and Liabilities

\begin{tabular}{|c|c|c|c|c|c|c|c|}
\hline \multirow{2}{*}{ Variables } & \multirow{2}{*}{ Prediction } & \multicolumn{3}{|c|}{ CASH_ETR } & \multicolumn{3}{|c|}{ GAAP_ETR } \\
\hline & & Coeff. & t-stat & Prob. & Coeff. & t-stat & Prob. \\
\hline $\mathrm{C}$ & $?$ & 0.083777 & 0.429026 & 0.6684 & -0.014200 & -0.058633 & 0.9533 \\
\hline FVD_A & - & -3.428468 & -3.513324 & $0.0001 * * *$ & -0.250485 & -0.278911 & 0.3903 \\
\hline FVD_L & + & 3.393829 & 3.498275 & $0.0001 * * *$ & 2.066456 & 2.079478 & 0.0097 **** \\
\hline LEV & $?$ & -0.008914 & -0.11596 & 0.9078 & 0.113852 & 1.690865 & $0.0923^{*}$ \\
\hline $\mathrm{ROA}$ & $?$ & -0.229497 & -3.636862 & $0.0003 * * *$ & -0.146751 & -1.807451 & $0.0721^{*}$ \\
\hline SIZE & $?$ & 0.009624 & 1.512814 & 0.1319 & 0.007619 & 0.954531 & 0.3409 \\
\hline CAPINT & $?$ & -0.058623 & -1.518547 & 0.1304 & -0.012813 & -0.350691 & 0.7262 \\
\hline \multicolumn{2}{|c|}{ Adj. R-squared } & 0.082769 & & & 0.068521 & & \\
\hline \multicolumn{2}{|c|}{ F-statistic } & 2.940102 & & & 2.635966 & & \\
\hline \multicolumn{2}{|c|}{ Prob (F-statistic) } & $0.001804^{*}$ **** & & & $0.017352 * *$ & & \\
\hline
\end{tabular}


Table 5

H2. The Association between Etrs and Hedging Derivative Assets and Liabilities

\begin{tabular}{|c|c|c|c|c|c|c|c|}
\hline \multirow{2}{*}{ Variables } & \multirow{2}{*}{ Prediction } & \multicolumn{3}{|c|}{ CASH_ETR } & \multicolumn{3}{|c|}{ GAAP_ETR } \\
\hline & & Coeff. & t-stat & Prob. & Coeff. & t-stat & Prob. \\
\hline $\mathrm{C}$ & $?$ & 0.075077 & 0.39189 & 0.6955 & 0.099239 & 0.401858 & 0.6882 \\
\hline FVHD_A & - & -5.363221 & -3.80953 & $0.0001 * * *$ & 2.467143 & 1.109623 & 0.1342 \\
\hline FVHD_L & + & 9.548645 & 1.23786 & 0.1086 & 4.350103 & 0.617932 & 0.2686 \\
\hline LEV & $?$ & 0.027236 & 0.34663 & 0.7292 & 0.114781 & 1.651384 & 0.1001 \\
\hline $\mathrm{ROA}$ & $?$ & -0.242372 & -4.01132 & $0.0001 * * *$ & -0.153224 & -1.859266 & $0.0644^{*}$ \\
\hline SIZE & $?$ & 0.009339 & 1.5190 & 0.1303 & 0.003681 & 0.453432 & 0.6507 \\
\hline CAPINT & $?$ & -0.05368 & -1.36407 & 0.1740 & 0.001205 & 0.032691 & 0.9740 \\
\hline \multicolumn{2}{|c|}{ Adj. R-squared } & 0.083636 & & & 0.049809 & & \\
\hline \multicolumn{2}{|c|}{ F-statistic } & 2.962285 & & & 1.878401 & & \\
\hline \multicolumn{2}{|c|}{ Prob (F-statistic) } & $0.001677 * * *$ & & & $0.085743^{*}$ & & \\
\hline
\end{tabular}

Similar to the result of $\mathrm{H} 1$ testing, regression results on $\mathrm{H} 3$ shows a significant negative (positive) association between Cash ETR and non-hedging derivative assets (liabilities). Table 6 presents $\mathrm{H} 3$ testing results. The association coefficient between cash ETR and non-hedging derivative assets (liabilities) is -1.963752 (2.197367) with probability $0.0244(0.0129)$ on one-tailed t-test. These associations imply that the higher (lower) the value of non-hedging derivative assets (liabilities) the lower the cash effective tax rate. This result suggests that firms delay realization of gains while at the same time accelerate the realization of losses on non-hedging derivatives to reduce current year tax payment.

GAAP ETR has a significant positive association with non-hedging derivative liabilities. The association coefficient is 2.428218 with probability 0.00555 on onetailed t-test. This implies the lower the non-hedging derivative liabilities, the lower the GAAP effective tax rate. It suggests firms harvest losses on non-hedging derivatives to reduce tax expense. Also, firms manage earnings by minimizing tax expense using nonhedging financial derivatives. 
Non-hedging derivatives represent a more aggressive level of tax planning strategy. Tax regulation in Indonesia allows an expense to be deductible if it is associated with the firm's ordinary business activities. Hedging activity is assumed to be an ordinary business activity whereas non-hedging not. However, Indonesia's tax rule does not explicitly limit hedging for tax purpose. Tax regulation also does not require special accounting treatment to account hedging derivatives for tax purpose. Firms can use a non-hedge accounting to record hedging activity. Thus, the losses on hedging derivatives are not offset by the gains of the hedged items. These losses significantly deduct taxable income due to the inexistence of the offset.

Table 6

H3. The Association between ETRs and Non-Hedging Derivative Assets and Liabilities

\begin{tabular}{|c|c|c|c|c|c|c|c|}
\hline \multirow{2}{*}{ Variables } & \multirow{2}{*}{ Prediction } & \multicolumn{3}{|c|}{ CASH_ETR } & \multicolumn{3}{|c|}{ GAAP_ETR } \\
\hline & & Coeff. & t-stat & Prob. & Coeff. & t-stat & Prob. \\
\hline $\mathrm{C}$ & $?$ & 0.046371 & 0.239493 & 0.8110 & 0.039229 & 0.160129 & 0.8729 \\
\hline FVHD_A & - & -5.378122 & -3.811908 & $0.0001^{* * *}$ & 2.624447 & 1.193350 & 0.11705 \\
\hline FVHD_L & + & 8.565337 & 1.093155 & 0.1378 & 3.829449 & 0.546799 & 0.29255 \\
\hline FVNHD_A & - & -1.963752 & -1.664244 & $0.0244 * *$ & -0.735493 & -0.750707 & 0.22685 \\
\hline FVNHD_L & + & 2.197367 & 1.957141 & $0.0129 * *$ & 2.428218 & 2.303136 & $0.0055 * * *$ \\
\hline $\mathrm{LEV}$ & $?$ & 0.020025 & 0.240186 & 0.8104 & 0.089248 & 1.284786 & 0.2003 \\
\hline $\mathrm{ROA}$ & $?$ & -0.237651 & -3.793119 & $0.0002 * * *$ & 0.141917 & -1.743598 & $0.0827^{*}$ \\
\hline SIZE & $?$ & 0.010509 & 1.687015 & 0.0931 & 0.006040 & 0.749040 & 0.4547 \\
\hline CAPINT & $?$ & -0.062706 & -1.571588 & 0.1176 & -0.007772 & -0.212078 & 0.8322 \\
\hline \multicolumn{2}{|c|}{ Adj. R-squared } & 0.088344 & & & 0.077172 & & \\
\hline \multicolumn{2}{|c|}{ F-statistic } & 2.736210 & & & 2.226517 & & \\
\hline \multicolumn{2}{|c|}{ Prob (F-statistic) } & $0.001855^{* * *}$ & & & $0.026712 * *$ & & \\
\hline
\end{tabular}




\section{Conclusion, Implication, and Limitation}

This study provides evidence that firms utilize financial derivatives to reduce their tax liabilities benefited by the ambiguity in tax regulations. The findings reveal firms coordinate gains and losses on derivatives timing recognition to avoid taxes. Furthermore, firms are likely to defer realization on hedging derivative's gains as tax regulation permit taxpayers to defer recognition of gains until derivative's position is closed. Moreover, firms are likely to accelerate derivative's losses realization to reduce taxable income. Also, firms are likely to involve in aggressive tax planning using nonhedging derivatives.

This study is of interest of the Indonesian tax authority since, at present, Indonesia does not have a specific tax regulation concerning derivative transactions. This study recommends policymakers to set a tax provision which treats derivative's gains and losses on a mark-to-market basis. Also, there should be an explicit limitation on financial derivatives to be classified as hedging instruments as firms involved in aggressive tax planning mostly employ non-hedging derivatives. For example, policymakers could adopt the accounting standard's requirements to categorize financial derivatives as an effective hedging instrument with some modifications in the business risk identification, hedging strategy and hedging effectiveness ratio. The adjustments are crucial since the accounting standard's hedge accounting requirements are relatively tight to be met which may increase taxpayer's compliance costs. More to the policy recommendations, to be categorized as hedging instrument for tax purpose, firms are required to apply matching principle by recognizing gains and losses on hedging instruments and hedged items in the same fiscal year.

\section{References}

Amindoni, Ayomi. 2016. Indonesia to Establish Clearing House for Derivatives in 2018. The Jakarta Post.

http://www.thejakartapost.com/news/2016/07/22/indonesia-to-establish-clearing-housefor-derivatives-in-2018.html

Barton, J. 2001. Does The Use of Financial Derivatives Affect Earnings Management Decisions? The Accounting Review, 76, 1-26. 
Donohoe, Michael Patrick. 2011a. Financial Derivatives in Corporate Tax Avoidance: An Empirical Examination of New Users. Working paper, University of Illinois at UrbanaChampaign.

2011b. Financial Derivatives in Corporate Tax Avoidance. Ph.D. Dissertation. UMI Dissertation Publishing.

. 2014. Financial Derivatives in Corporate Tax Avoidance: A Conceptual Perspective. Journal of the American Taxation Association.

2015. The Economic Effects of Financial Derivatives on Corporate

Tax Avoidance. Journal of Accounting and Economics 59 (2915) 1 - 24

Ghoradia, Shefali. Taxation of Financial Derivatives. Nishith Desai Associates.

Graham, John R \& Rogers, Daniel A. 2002. Do Firms Hedge in Response to Tax Incentives. The Journal of Finance Vol LVII, No. 2.

Hanlon, Michelle, and Shane Heitzman. 2010. A Review of Tax Research. Journal of Accounting and Economics 50 (2010) 127-178.

Lee, Yoojin. 2017. The Impact of Hedging and Non-Hedging Derivatives on Tax Avoidance. Ph.D. dissertation, University of California, Irvine.

Murwaningsari, E. 2011. Hubungan Derivatif Keuangan dan Discretionary Accrual sebagai Alat Manajemen Laba serta Pengaruh terhadap Relevansi Nilai dari Laba dan Ekuitas. Disertasi Doktoral. Program Pascasarjana Ilmu Akuntansi, Fakultas Ekonomi Universitas Indonesia.

Oktavia dan Dwi Martani. 2013. Tingkat Pengungkapan dan Penggunaan Derivatif Keuangan Dalam Aktivitas Penghindaran Pajak. Jurnal Akuntansi dan Keuangan Indonesia Volume 10 Nomor 2, Desember 2013.

Pincus, M. and S. Rajgopal. 2002. The Interaction between Accrual Management and Hedging: Evidence from Oil and Gas Firms. The Accounting Review, 77 (1), 127-160.

Scott, W. R. 2009. Financial Accounting Theory. 7th edition. Toronto: Prentice-Hall.

Smith, Clifford W. dan Rene M. Stulz. 1985. The Determinants of Firms' Hedging Policies. Journal of Financial And Quantitative Analysis.

Victor, Andreas. 2008. Perlakuan Pajak Penghasilan atas Transaksi Derivatif Berbentuk Waran. Inside Tax Edisi 08, Juni 2008, Danny Darussalam Tax Center

Wyman, Oliver. 2013. The Asian OTC Derivatives Market. A Study Prepared for ISDA.

Zeng, Tao. 2001. Tax Planning Using Derivative Instruments and Firm Market Valuation Using Clean Surplus Accounting. Queen's University.

Zeng, Tao. 2014. Derivative Financial Instruments, Tax Aggressiveness, and Firm Market Value. Journal of Financial Economic Policy Vol. 6 No. 4, 2014. 
The Indonesian Journal of Accounting Research - May, Vol. 21, No.2, 2018

intentionally blank 